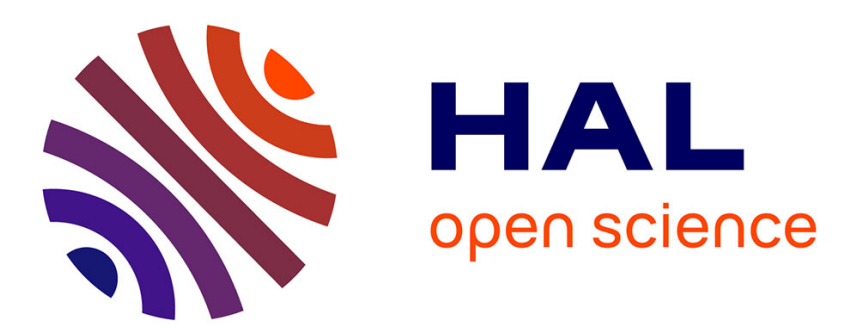

\title{
Thermodynamic interpretation of neptunium coprecipitation in uranophane for application to the Yucca Mountain repository
}

W.M. Murphy, Bernd Grambow

\section{- To cite this version:}

W.M. Murphy, Bernd Grambow. Thermodynamic interpretation of neptunium coprecipitation in uranophane for application to the Yucca Mountain repository. Radiochimica Acta, 2008, 96, pp.563567. 10.1524/ract.2008.1537 . in2p3-00346838

HAL Id: in2p3-00346838

https://hal.in2p3.fr/in2p3-00346838

Submitted on 14 Dec 2008

HAL is a multi-disciplinary open access archive for the deposit and dissemination of scientific research documents, whether they are published or not. The documents may come from teaching and research institutions in France or abroad, or from public or private research centers.
L'archive ouverte pluridisciplinaire HAL, est destinée au dépôt et à la diffusion de documents scientifiques de niveau recherche, publiés ou non, émanant des établissements d'enseignement et de recherche français ou étrangers, des laboratoires publics ou privés. 
Thermodynamic interpretation of neptunium coprecipitation in uranophane for application to the Yucca Mountain repository

By William M. Murphy ${ }^{1}$ and Bernd Grambow ${ }^{2}$

${ }^{1}$ Department of Geological and Environmental Sciences, California State University, Chico, California 95929 USA; wmurphy@csuchico.edu

${ }^{2}$ Radiochemistry Group, SUBATECH, Ecole des Mines de Nantes, 44307 Nantes, France; grambow@subatech.in2p3.fr

Neptunium / Coprecipitation / Uranophane / Aqueous Speciation / Yucca Mountain

Summary. Interpretation and modeling of recent experimental data [1] yield thermodynamic constants for the distribution of trace $\mathrm{Np}(\mathrm{V})$ between aqueous solutions and uranophane. These data indicate that neptunyl is relatively excluded from the uranyl mineral structure, but the interpretation depends on uncertain aqueous speciation and thermodynamic properties as a function of temperature. Despite Np exclusion, the low calculated solubility of uranophane at $25^{\circ} \mathrm{C}$ under conditions relevant to the proposed nuclear waste repository at Yucca Mountain, Nevada, leads to Np concentrations at equilibrium with a $\mathrm{Np}$-bearing uranophane solid solution that are low compared to concentrations invoked as solubility limits in Yucca Mountain performance assessments.

\section{Introduction}

Spent nuclear fuel alteration under oxidizing conditions at the high level nuclear waste repository at Yucca Mountain, Nevada, will produce secondary uranyl minerals (e.g., $[2,3,4,5,6,7,8])$. Much speculation attends the role of these minerals in sequestering trace 
radionuclides. For example, Burns et al. [9] provided crystallographic data suggesting that ions of actinide elements would substitute for uranyl ions in secondary uranyl minerals. Murphy and Codell [10] modeled incorporation of radionuclides in secondary schoepite, arbitrarily assigning their proportions relative to uranium to be the same as in the spent fuel. Then, adopting a source term model for radionuclide release controlled by schoepite solubility, they showed that modeled repository performance was substantially improved compared to cases based on empirical spent fuel dissolution rates. Chen et al. [11] used data from spent fuel alteration studies under conditions resembling those at Yucca Mountain (e.g., [12]) to speculate that the $\mathrm{Np} / \mathrm{U}$ ratio in releases from spent fuel corresponded to the ratio in the fuel and to infer that the $\mathrm{Np} / \mathrm{U}$ ratio in secondary uranyl products was the same. Promising reports of preferential Np incorporation in secondary dehydrated schoepite in spent fuel alteration tests [13] were shown later to be incorrect [14]. Despite this interest, investigations of the thermodynamic, kinetic, and solid solution properties of uranyl minerals are currently inadequate to predict reliably their effects on repository performance at Yucca Mountain.

\section{Experimental Incorporation of $\mathrm{Np}$ in Uranyl Minerals}

Burns et al. [1] synthesized uranophane, Na-compreignacite, $\beta-\mathrm{UO}_{2}(\mathrm{OH})_{2}$, and metaschoepite containing neptunyl in variable trace amounts in solid solution at $75^{\circ} \mathrm{C}$ to $100^{\circ} \mathrm{C}$. These crucial data apparently reflect solid-aqueous exchange equilibria and show that the $\mathrm{Np} / \mathrm{U}$ ratio for each solid phase was proportional to the total aqueous $\mathrm{Np}(\mathrm{V})$ concentrations in the starting solutions. The synthesis studies revealed that $\mathrm{Np}$ 
incorporation was limited in metaschoepite and in $\beta-\mathrm{UO}_{2}(\mathrm{OH})_{2}$, and that $\mathrm{Np}$ solid solution in uranophane and in Na-compreignacite was substantially greater [1].

Aqueous $\mathrm{Np}$ concentrations in the synthesis experiments ranged to near $500 \mathrm{ppm}$ [1]. Steady-state total $\mathrm{Np}$ concentrations in oxidizing solubility studies range from $10^{-5}$ to $10^{-3} \mathrm{M}$ (about 2 to $200 \mathrm{ppm}$ ) under oxidizing, near neutral $\mathrm{pH}$ conditions relevant to Yucca Mountain $[15,16]$. In contrast, performance assessment studies for the Yucca Mountain repository adopt $\mathrm{Np}$ solubility limits at approximately 0.1 to $1 \mathrm{ppm}\left(4 \times 10^{-7}\right.$ to $\left.4 \times 10^{-6} \mathrm{M}\right)$ at $\mathrm{pH} 7$ to 8 [17]. These limits are based on model water compositions and calculated $\mathrm{NpO}_{2}$ and $\mathrm{Np}_{2} \mathrm{O}_{5}$ solubilities, and they provide reasonable upper bounds to empirical Np concentrations in spent fuel dissolution studies (e.g., [18]), which were not solubility experiments.

The maximum initial aqueous Np concentration in the Burns et al. [1] Np-bearing uranophane synthesis experiments was about $350 \mathrm{ppm}\left(1.5 \times 10^{-3} \mathrm{M}\right)$. The corresponding $\mathrm{Np} / \mathrm{U}$ ratio in synthetic uranophane was reported to be about $400 \mathrm{ppm}(0.4 \mathrm{mg} \mathrm{Np} / \mathrm{g}$ $\mathrm{U}+\mathrm{Np}$ ). In contrast, the $\mathrm{Np} / \mathrm{U}$ ratio in spent nuclear fuel is larger, approximately 1000 ppm at 200 years after discharge in fuel with a burnup of $45 \mathrm{GWd} / \mathrm{tHM}$. If the proportionality between the $\mathrm{Np}$ content of uranophane crystals and the aqueous $\mathrm{Np}$ concentration observed by Burns et al. [1] was valid for Yucca Mountain conditions, then the $\mathrm{Np} / \mathrm{U}$ ratio in uranophane would be about $1 \mathrm{ppm}$ for the nominal aqueous $\mathrm{Np}$ solubility limit of $1 \mathrm{ppm}$. This value is three orders of magnitude lower than the $\mathrm{Np} / \mathrm{U}$ ratio in spent fuel suggesting that sequestration of $\mathrm{Np}$ in uranophane would provide an insignificant sink. However, this interpretation neglects the dependence of the $\mathrm{Np}$ 
distribution on differences in aqueous speciation and temperature between the experiments and Yucca Mountain.

\section{Interpretation of Aqueous Solutions and Solution-Solid Equilibria}

Distribution coefficients typically relate the ratio of concentrations of trace to host elements in the solid to the ratio of the total concentrations of these elements in the aqueous phase. This approach is practical, but neglects aqueous speciation and nonideal mixing in both phases, and it cannot be applied outside the range of experimental conditions for which the data are determined. Alternatively, predictive thermodynamic and kinetic relations apply generally to solid solution-aqueous solution relations (e.g., $[19,20,21])$. A thermodynamic interpretation and predictive application of trace element distribution data from the $\mathrm{Np}$-uranophane synthesis experiments of Burns et al. [1] could help validate their conclusion that "likely incorporation of $\mathrm{Np}^{5+}$ into the structure of uranophane ... could have a profound impact on the long-term mobility of $\mathrm{Np}$ in the [Yucca Mountain] repository ...." However, this contention is subject to substantial uncertainty because of important differences between the experimental conditions and the likely conditions at Yucca Mountain, and because of the minimal experimental coprecipitation of $\mathrm{Np}$ adduced above.

Complete aqueous solution compositions were not reported for the $\mathrm{Np}$-bearing uranyl mineral synthesis experiments [1], but they can be estimated based on mass balance and thermodynamic controls. Reagents used to synthesize Np-bearing uranophane and corresponding calculated total molalities of individual components are given in Table I. The amount of added perchloric acid was calculated to match the 
reported $\mathrm{pH}$, and all concentrations were adjusted accordingly. Complete dissolution of reagents and no mineral precipitation were assumed to calculate an equilibrium aqueous speciation model for the starting solution at $25^{\circ} \mathrm{C}$ using PHREEQC [22]. Incomplete dissolution of reagents or precipitation, as suggested by the cooling model presented below, could affect these results.

The resulting model solution is dominated by acetate and acetate complexes. Data for aqueous mono-, di-, and tri-acetate complexes of uranyl ions and monoacetate complexes for neptunyl ions were taken from Martel and Smith [23]. Enthalpies of reaction are available only for uranyl acetate complexes, not neptunyl complexes. Other aqueous species data were taken from the LLNL (v8.R6) data base except as noted.

Experimental synthesis of $\mathrm{Np}$-bearing uranophane was conducted at $100^{\circ} \mathrm{C}[1]$. An equilibrium model for the aqueous solution at $100^{\circ} \mathrm{C}$ was generated using the component masses from the $25^{\circ} \mathrm{C}$ solution model (Table I) and adjusting the $\mathrm{pH}$ to achieve charge balance. A batch PHREEQC model was then used to simulate precipitation at $100^{\circ} \mathrm{C}$ of $\mathrm{Np}$-bearing uranophane with the $\mathrm{Np} / \mathrm{U}$ ratio reported in the experimental study using thermodynamic data described below. The principal aqueous species in the resulting solution are given in Table II. The quantity of Np-bearing uranophane precipitated in the model was $0.141 \mathrm{moles} / \mathrm{kg} \mathrm{H}_{2} \mathrm{O}$. The total $\mathrm{Np}(\mathrm{V})$ concentrations in the model solutions were $1.27 \times 10^{-3} \mathrm{~m}$ at $25^{\circ} \mathrm{C}$ and $1.22 \times 10^{-3} \mathrm{~m}$ at $100^{\circ} \mathrm{C}$. This result is supported qualitatively by the observation by P.C. Burns (personal communication) that only a small fraction of $\mathrm{Np}$ precipitated. 
The thermodynamic properties of the Np-bearing uranophane were based on the

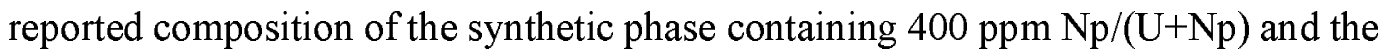
equilibrium mass action relation for the exchange reaction $\mathrm{Ca}_{0.5} \mathrm{UO}_{2} \mathrm{SiO}_{3}(\mathrm{OH}) \cdot 2.5 \mathrm{H}_{2} \mathrm{O}+\mathrm{NpO}_{2}^{+}+\mathrm{H}^{+} \Leftrightarrow \mathrm{Ca}_{0.5} \mathrm{NpO}_{2} \mathrm{SiO}_{2}(\mathrm{OH})_{2} \cdot 2.5 \mathrm{H}_{2} \mathrm{O}+\mathrm{UO}_{2}{ }^{2+}$

\section{Uranophane} Np-uranophane

The stoichiometry of the Np-uranophane is inferred from the likely substitution of $\mathrm{NpO}_{2}{ }^{+}$ for $\mathrm{UO}_{2}{ }^{2+}$ and coupled protonation of structural oxygen. The $\mathrm{Np}$ distribution thus depends on $\mathrm{pH}$ as well as on the hydrolysis and complexation of aqueous uranyl and neptunyl. The exchange reaction (1) is the difference between two dissolution reactions

$\mathrm{Ca}_{0.5} \mathrm{UO}_{2} \mathrm{SiO}_{3}(\mathrm{OH}) \cdot 2.5 \mathrm{H}_{2} \mathrm{O}+3 \mathrm{H}^{+} \Leftrightarrow 0.5 \mathrm{Ca}^{2+}+\mathrm{UO}_{2}{ }^{2+}+\mathrm{Si}(\mathrm{OH})_{4}+2.5 \mathrm{H}_{2} \mathrm{O}$

$\mathrm{Ca}_{0.5} \mathrm{NpO}_{2} \mathrm{SiO}_{2}(\mathrm{OH})_{2} \cdot 2.5 \mathrm{H}_{2} \mathrm{O}+2 \mathrm{H}^{+} \Leftrightarrow 0.5 \mathrm{Ca}^{2+}+\mathrm{NpO}_{2}^{+}+\mathrm{Si}(\mathrm{OH})_{4}+2.5 \mathrm{H}_{2} \mathrm{O}$

The equilibrium constant $\left(\mathrm{K}_{\mathrm{x}}\right)$ for the exchange reaction (1) is written

$\mathrm{K}_{\mathrm{x}}=\mathrm{K}_{\mathrm{Ur}} / \mathrm{K}_{\mathrm{Np}-\mathrm{Ur}}=\left(\mathrm{a}_{\mathrm{Np}-\mathrm{Ur}}\right)\left(\mathrm{a}_{\mathrm{UO} 2^{2+}}\right) /\left[\left(\mathrm{a}_{\mathrm{Ur}}\right)\left(\mathrm{a}_{\mathrm{NpO}^{+}}\right)\left(\mathrm{a}_{\mathrm{H}^{+}}\right)\right]$

where a stands for activity, $\mathrm{Ur}$ and $\mathrm{Np}$-Ur denote the uranophane and $\mathrm{Np}$-uranophane endmembers, respectively, of the solid solution, and $\mathrm{K}_{\mathrm{Ur}}$ and $\mathrm{K}_{\mathrm{Np} \text {-Ur }}$ stand for the equilibrium constants for dissolution reactions (2) and (3). Reported experimental data provide a value at $25^{\circ} \mathrm{C}$ for $\log \mathrm{K}_{\mathrm{Ur}}=5.41$ [8,24,25]. Using an estimated standard enthalpy for the uranophane dissolution reaction (2), $-65.1 \mathrm{~kJ} / \mathrm{mole}[8]$, the $100^{\circ} \mathrm{C}$ value of $\log \mathrm{K}_{\mathrm{Ur}}=3.12$ is obtained from the van't Hoff equation. Assuming an ideal solid solution, $\mathrm{a}_{\mathrm{NpUr}}$ and $\mathrm{a}_{\mathrm{Ur}}$ equal the reported experimental mole fractions of the components, $4 \times 10^{-4}$ and $1-4 \times 10^{-4}=0.9996$, respectively. Values for $\mathrm{K}_{\mathrm{NpUr}}$ and $\mathrm{K}_{\mathrm{x}}$ were then obtained by iteratively fitting the mole fractions of the solid components and the aqueous uranyl, 
neptunyl, and hydrogen ion activities provided by the equilibrium batch precipitation model at $100^{\circ} \mathrm{C} . \log \mathrm{K}_{\mathrm{Np}-\mathrm{Ur}}=4.50$ and $\log \mathrm{K}_{\mathrm{x}}=-1.38$ were obtained for $100^{\circ} \mathrm{C}$.

The standard state enthalpy of formation of the hypothetical Np-uranophane endmember at $25^{\circ} \mathrm{C}$ can be estimated by summing structural component enthalpies in their stoichiometric proportions for $\mathrm{CaO}, \mathrm{H}_{2} \mathrm{O}$ (structural), and $\mathrm{H}_{2} \mathrm{O}$ (hydration) from [26], $\mathrm{SiO}_{2}$ from [27], and the standard state enthalpy of formation of $\mathrm{Np}_{2} \mathrm{O}_{5}(\mathrm{cr})$ from [28]. For $\mathrm{Ca}_{0.5} \mathrm{NpO}_{2} \mathrm{SiO}_{2}(\mathrm{OH})_{2} \cdot 2.5 \mathrm{H}_{2} \mathrm{O}$, the estimated $\Delta \mathrm{H}_{\mathrm{f}}^{\circ}{ }_{\mathrm{Np}-\mathrm{Ur}}=-3394.5 \mathrm{~kJ} / \mathrm{mole}$. At $25^{\circ} \mathrm{C}$ the standard enthalpy for the dissolution reaction (3) can be estimated from $\Delta \mathrm{H}^{\circ}{ }_{\mathrm{Np}-\mathrm{Ur}}=0.5 \Delta_{\mathrm{f}} \mathrm{H}_{\mathrm{Ca}^{2+}}^{\circ}+\Delta_{\mathrm{f}} \mathrm{H}^{\circ}{ }_{\mathrm{NpO} 2^{+}}+\Delta_{\mathrm{f}} \mathrm{H}_{\mathrm{Si}(\mathrm{OH}) 4}^{\circ}+2.5 \Delta_{\mathrm{f}} \mathrm{H}_{\mathrm{H} 2 \mathrm{O}}^{\circ}-\Delta_{\mathrm{f}} \mathrm{H}^{\circ}{ }_{\mathrm{Np}-\mathrm{Ur}}=-26.7 \mathrm{~kJ} / \mathrm{mol}$ using standard enthalpies of formation for the aqueous species from [28]. The corresponding standard enthalpy of the exchange reaction (1) at $25^{\circ} \mathrm{C}$ is $-38.4 \mathrm{~kJ} / \mathrm{mole}$, making use of the standard enthalpy estimated by a similar method for the uranophane dissolution reaction (2) from [8].

The derived equilibrium constant for the Np-uranophane dissolution reaction (3) at $100^{\circ} \mathrm{C}$ was extrapolated to $25^{\circ} \mathrm{C}$ using the van't Hoff relation assuming a constant standard enthalpy of reaction, yielding $\log \mathrm{K}_{\mathrm{Np}-\mathrm{Ur}, 298}=5.44$. The corresponding equilibrium constant for the exchange reaction (1) at $25^{\circ} \mathrm{C}$ is $\log \mathrm{K}_{\mathrm{x}, 298}=-0.03$ using the experimental value of $\log \mathrm{K}_{\mathrm{Ur}, 298}=5.41[8,25]$.

Burns et al. [1] reported that the Np-bearing uranophane produced in their experiments was accompanied by crystals of $\mathrm{Na}$ uranyl acetate, which were subsequently removed by washing. Temperature dependent solubility data [29] were interpreted to provide values of $\log \mathrm{K}_{\mathrm{NaUAc}}=-2.55$ and $\Delta \mathrm{H}^{\circ}{ }_{\mathrm{NaUAc}}=20.44 \mathrm{~kJ} /$ mole for the reaction $\mathrm{NaUO}_{2}(\mathrm{CHCOO})_{3} \Leftrightarrow \mathrm{Na}^{+}+\mathrm{UO}_{2}(\mathrm{CHCOO})_{3}{ }^{-}$ 
Using these data, our $100^{\circ} \mathrm{C}$ model indicates that the experimental solution was undersaturated with respect to $\mathrm{NaUO}_{2}(\mathrm{CHCOO})_{3}$, so its precipitation did not affect the aqueous speciation. The $100^{\circ} \mathrm{C}$ model solution and $\mathrm{Np}$-bearing uranophane precipitate were reequilibrated in a PHREEQC model at $25^{\circ} \mathrm{C}$. The low temperature solution became supersaturated in Na uranyl acetate, which explains its presence in the products of the synthesis experiment.

\section{Discussion of Uncertainties}

A primary objective of this study is to address the uncertainty associated with applying the experimental $\mathrm{Np}$ coprecipitation data from Burns et al. [1] to conditions at the Yucca Mountain repository. A thermodynamic approach is deemed to be the most robust method for making such an extrapolation even if some thermodynamic data must be estimated at this time. Burns et al. [1] reported that their analytical data are expected to be accurate within about 10 percent, with uncertainties in $\mathrm{Np}$ concentrations up to 15 percent and mostly less than 5 percent based on duplicate analyses. As far as possible, thermodynamic data used in this analysis are taken from the most recent NEA compilation [28] with uncertainties evaluated in that report. Estimates of standard state enthalpies of formation for uranophane and $\mathrm{Np}$-uranophane make use of $\mathrm{U}$ and $\mathrm{Np}$ data from that compilation. The PHREEQC data base used in the aqueous speciation and reaction path calculations for this study incorporates the NEA data.

Parallel assumptions were made in estimations of the standard state enthalpies of formation for uranophane [8] and for Np-uranophane, which limits uncertainty in the 
estimated standard enthalpy for the exchange reaction between them. However, uncertainties are associated with the inferred stoichiometry of the exchange reaction. The assumption of constant standard enthalpy for the exchange reaction between $25^{\circ} \mathrm{C}$ and $100^{\circ} \mathrm{C}$ permits a thermodynamically based extrapolation of the higher temperature experimental data to the relevant temperature for the Yucca Mountain repository. Neglecting the temperature dependence of the standard enthalpy of exchange should introduce small errors relative to other uncertainties reiterated below.

Speciation of aqueous neptunyl is uncertain in acetic acid solutions at elevated temperature. Notably absent is the enthalpy of dissociation for aqueous $\mathrm{NpO}_{2}\left(\mathrm{CH}_{3} \mathrm{COO}\right)$. To examine the possible significance of this uncertainty, using the enthalpy of dissociation of aqueous $\mathrm{UO}_{2}\left(\mathrm{CH}_{3} \mathrm{COO}\right)^{-}$for the neptunyl acetate complex would result in a difference of about 25 percent in the derived value of $K_{x}$.

Results reported in this paper, including estimated thermodynamic data, are model dependent, and important remaining uncertainties are recognized in our interpretation. Nevertheless, we conclude that the thermodynamic approach in this paper presently permits the most robust extrapolation the experimental coprecipitation data [1] to conditions relevant to the Yucca Mountain repository.

\section{Application to the Yucca Mountain High-Level Nuclear Waste Repository}

Potential sequestration of $\mathrm{Np}$ in uranophane by solid solution can be evaluated by modeling equilibrium among representative Yucca Mountain waters and Np-bearing uranophane using the thermodynamic ion exchange data estimated above. Repository chemistry will be controlled eventually by the ambient geochemical system with added 
masses of iron, uranium, and other materials including radionuclides. Stable mineral assemblages are likely to include uranophane as an alteration product of spent nuclear fuel.

The ambient groundwater chemistry in the unsaturated zone at Yucca Mountain is generally dilute, oxidizing, slightly alkaline, rich in silica and bicarbonate, and variable in major ion concentrations (e.g., [30,31]). Sampling and analysis of pore water from the hydrologically unsaturated zone are challenging, and reported data are subject to reinterpretation (e.g., [32]). Perched water also occurs at Yucca Mountain, and it may reflect the chemistry of relatively mobile fracture water. Two unsaturated zone water chemistries representative of Yucca Mountain are given in Table III. The pore water data were reinterpreted following the approach of Browning et al. [32], which imposes equilibrium aqueous speciation, electroneutrality, and equilibrium $\mathrm{CO}_{2}$ fugacity based on gas phase measurements, and results in adjustments to the reported $\mathrm{pH}$ and bicarbonate concentration. Equilibrium aqueous speciation for the perched water included small adjustment of the reported bicarbonate value to achieve charge balance. Speciation calculations were performed with EQ3NR, v7.2c with the data0.cmp.v8.R6 data base (e.g., [33]) and the uranophane data noted above.

Table IV summarizes model aqueous uranium and neptunium speciation in Yucca Mountain groundwaters (Table III) at equilibrium with Np-bearing uranophane having a $\mathrm{Np} / \mathrm{U}$ ratio of $10^{-3}$. This value corresponds to the $\mathrm{Np} / \mathrm{U}$ ratio in spent nuclear fuel and it is thus a reasonable upper limit to the $\mathrm{Np}$ content of secondary uranophane that may form by alteration of spent nuclear fuel. The resulting equilibrium model indicates that neptunyl is relatively excluded from the uranophane structure. For experimental 
conditions at $100^{\circ} \mathrm{C}$, the calculated aqueous neptunyl/uranyl free ion ratio is 58 (Table II), the calculated total aqueous $\mathrm{Np} / \mathrm{U}$ ratio is 0.04 , and the experimentally observed $\mathrm{Np} / \mathrm{U}$ ratio in coexisting uranophane was $4 \times 10^{-4}$ [1]. For modeled conditions at Yucca Mountain at equilibrium with $\mathrm{Np}$-bearing uranophane, the aqueous neptunyl/uranyl free ion ratio is calculated to be near $10^{5}$ for a $\mathrm{Np} / \mathrm{U}$ ratio in coexisting uranophane of $10^{-3}$. Total aqueous $\mathrm{Np} / \mathrm{U}$ concentration ratios are much smaller than free neptunyl/uranyl ion ratios primarily because of strong carbonate complexation of aqueous uranyl in the Yucca Mountain waters and because of uranyl acetate complexation in the experimental studies. For the Yucca Mountain models, the total aqueous $\mathrm{Np} / \mathrm{U}$ ratios are $5 \times 10^{-3}$ to $8 \times 10^{-3}$ for perched and pore waters, respectively. These values are within an order of magnitude of the ratio of $\mathrm{Np} / \mathrm{U}$ in coexisting uranophane $\left(10^{-3}\right)$.

Despite relative $\mathrm{Np}$ exclusion from the uranophane structure, the low calculated solubility of uranophane containing trace $\mathrm{Np}$ under ambient conditions at Yucca Mountain results in total aqueous $\mathrm{Np}$ concentrations near $10^{-9}$ molal $\left(2 \times 10^{-4} \mathrm{ppm}\right)($ Table IV). This value is orders of magnitude lower than the solubility limits for $\mathrm{Np}$ in Yucca Mountain performance assessment models [17].

\section{Conclusions}

Experimental synthesis data for $\mathrm{Np}$ coprecipitation in uranophane [1] are crucially important for evaluation of $\mathrm{Np}$ sequestration in the proposed nuclear waste repository at Yucca Mountain. Thermodynamic interpretations of experimental results are necessary before they can be used to guide repository performance evaluations. Uncertainties in 
aqueous acetate chemistry, particularly at elevated temperature, complicate the interpretation of the experimental results.

Experimental data [1] show that $\mathrm{NpO}_{2}{ }^{+}$is relatively excluded from the uranophane structure, and this same general conclusion is reached in our thermodynamic extrapolation of the experimental data to Yucca Mountain conditions. Nevertheless, the low calculated solubility of uranophane under Yucca Mountain conditions leads to low aqueous $\mathrm{Np}$ concentrations at equilibrium with uranophane containing trace amounts of $\mathrm{Np}$ in solid solution. Neptunium coprecipitation in uranophane could be an effective process for long term nuclear waste isolation at Yucca Mountain under ambient geochemical conditions.

\section{Acknowledgments}

We appreciate information provided by Peter Burns on details of the synthesis-exchange experiments. Comments from three anonymous reviewers contributed to clarifying the discussion 


\section{References}

1. Burns, P.C., Deely, K.M., Skanthakumar, S.: Neptunium incorporation into uranyl compounds that form as alteration products of spent nuclear fuel: Implications for geologic repository performance, Radiochim. Acta 92, 151 (2004).

2. Bruton, C.J., Shaw, H.F.: Geochemical simulation of reaction between spent fuel waste form and J-13 water at $25^{\circ} \mathrm{C}$ and $90^{\circ} \mathrm{C}$, MRS Symp. Proc. 84, 485 (1987).

3. Bates, J.K., Tani, B.S., Veleckis, E., Wronkiewicz, D.J.: Identification of secondary phases formed during reaction of $\mathrm{UO}_{2}$ with EJ-13 water, MRS Symp. Proc. 176, 499 (1990).

4. Wilson, C.N.: Results from long term dissolution tests using oxidized spent fuel, MRS Symp. Proc. 212, 197 (1991).

5. Finch, R.J., Ewing, R.C.: Alteration of natural uranyl oxide hydrates in Si-rich groundwaters: Implications for uranium solubility, MRS Symp. Proc. 257, 465 (1992).

6. Murphy, W.M., Pearcy, E.C.: Source-term constraints for the proposed repository at Yucca Mountain, Nevada, derived from the natural analog at Peña Blanca, Mexico, MRS Symp. Proc. 257, 531 (1992).

7. Pearcy, E.C., Prikryl, J.D., Murphy, W.M., Leslie, B.W.: Alteration of uraninite from the Nopal I deposit, Peña Blanca District, Chihuahua, Mexico, compared to degradation of spent nuclear fuel in the proposed U.S. high-level nuclear waste repository at Yucca Mountain, Nevada, App. Geochem. 9, 713 (1994).

8. Murphy, W.M.: Hydrothermal phase relations among uranyl minerals at the Nopal I analog site. MRS Symp. Proc. 985, 53 (2007).

9. Burns, P.C., Ewing, R.C., Miller, M.L.: Incorporation mechanisms of actinide elements into the structures of $\mathrm{U}^{6+}$ phases formed during the oxidation of spent nuclear fuel, J. Nucl. Mat., 245, 1 (1997).

10. Murphy, W.M., Codell, R.C.: Alternate source term models for Yucca Mountain performance assessment based on natural analog data and secondary mineral solubility. MRS Symp. Proc. 556, 551 (1999).

11. Chen, Y., Loch, A.R., Wolery, T.J., Steinborn, T.L., Brady, P.V., Stockman, C.T.: Solubility evaluation for Yucca Mountain TSPA-SR. MRS Symp. Proc. 713, 775 (2002).

12. Finn, P.A., Buck, E.C., Gong, M., Hoh, J.C., Emery, J.W., Hafenrichter, L.D., Bates, J.K : Colloidal products and actinide species in leachate from spent nuclear fuel, Radiochim. Acta 66/67, 189 (1994).

13. Buck, E.C., Finch, R.J., Finn, P.A., Bates, J.K.: Retention of neptunium in uranyl alteration phases formed during spent fuel corrosion, MRS Symp. Proc. 506, 87 (1998).

14. Fortner, J.A., Finch, R.J., Kropf, A.J., Cunnane, J.C.: Re-evaluating neptunium in uranyl phases derived from corroded spent fuel, Proc. Int. High Level Rad. Waste Mgmt. (Las Vegas, NV), 764 (2003).

15. Nitsche, H.: Solubility studies of transuranium elements for nuclear waste disposal: Principles and overview, Radiochim. Acta 52/53, 3 (1991). 
16. Efurd, D.W., Runde, W., Banar, J.C., Janecky, D.R., Kaszuba, J.P., Palmer, P.D., Roensch, F.R., Tait, C.D.: Neptunium and plutonium solubilities in a Yucca Mountain Groundwater. Environ. Sci. Tech. 32, 3893 (1998).

17. Sassani, D.C., Van Luik, A., Summerson, J.: Neptunium solubility in the near-field environment of a proposed Yucca Mountain repository, MRS Symp. Proc. 932, 991 (2006).

18. Wilson, C.N.: Results from NNWSI Series 3 Spent Fuel Dissolution Tests. PNL7170, June, 1990.

19. Plummer, L.N., Busenberg, E.: Thermodynamics of aragonite-strontianite solid solutions: Results from stoichiometric solubility at 25 and $76^{\circ} \mathrm{C}$, Geochim.

Cosmochim. Acta 51, 1393 (1987).

20. Murphy, W.M., Smith, R.W.: Irreversible dissolution of solid solutions: A kinetic and stoichiometric model, Radiochim. Acta, 44/45, 395 (1988).

21. Pina, C.M., Enders, M., Putnis, A.: The composition of solid solutions crystallizing from aqueous solutions: the influence of supersaturation and growth mechanisms. Chem. Geol. 168, 195 (2000).

22. Parkhurst, D.L., Appelo, T.: User's guide to PHREEQC (Version 2) - A Computer Program for Speciation, Batch-Reaction, One-Dimensional Transport, and Inverse Geochemical Calculations, USGS WRI 99-4259, Denver, CO (1999).

23. Martel, A.E., Smith, R.M.: NIST standard reference data base version 46: Critical Selected Stability Constants of Metal Complexes Database Version 2 (1995).

24. Prikryl, J.D., Murphy, W.M.: The dissolution of uranophane in $\mathrm{CaCl}_{2}-\mathrm{SiO}_{2}$ (aq) test solutions, MRS Symp. Proc. 824, 189 (2004).

25. Prikryl, J.D.: Uranophane dissolution and growth in $\mathrm{CaCl}_{2}-\mathrm{SiO}_{2}(\mathrm{aq})$ test solutions, Geochim. Cosmochim. Acta 72, 4508 (2008).

26. Chen, F., Ewing, R.C., Clark, S.B.: The Gibbs free energies and enthalpies of formation of $\mathrm{U}^{6+}$ phases: An empirical method of prediction. Amer. Min. 84, 650 (1999).

27. Chermak, J.A., Rimstidt, J.D.: Estimating the thermodynamic properties $\left(\Delta \mathrm{G}_{\mathrm{f}}^{\circ}\right.$ and $\left.\Delta \mathrm{H}_{\mathrm{f}}{ }^{\circ}\right)$ of silicate minerals at $298 \mathrm{~K}$ from the sum of polyhedral contributions, Amer. Min. 74, 1023 (1989).

28. Guillamont, R., Fanghänel, T, Fuger, J., Grenthe, I., Neck, V., Palmer, D. A., Rand, M.H. : Update on the Chemical Thermodynamics of Uranium, Neptunium, Plutonium, Americium and Technetium, Elsevier, Amsterdam 2003, p. 919.

29. Hála, J., Navratil, J.D. : IUPAC-NIST solubility data series. 74. Actinide carbon compounds. J. Phys. Chem. Ref. Data 30, 531 (2001).

30. Yang, I.C., Rattray, G.W., Yu, P.: Interpretation of chemical and isotopic data from boreholes in the unsaturated zone at Yucca Mountain, Nevada. USGS WRI 96-4058 (1996).

31. Yang, I.C., Peterman, Z.E., Scofield, K.M.: Chemical analyses of pore water from boreholes USW SD-6 and USW WT-24, Yucca Mountain, Nevada, J. Contam. Hydro. 62-63, 361 (2003).

32. Browning, L., Murphy, W.M., Leslie, B.W., and Dam, W.L.: Thermodynamic interpretations of chemical analyses of unsaturated zone water form Yucca Mountain, Nevada, MRS Symp. Proc. 608, 237 (2000). 
33. Wolery, T.J.: EQ3/6, A Software Package for Geochemical Modeling of Aqueous Systems. UCRL-MA-1 10662, LLNL, Livermore, CA (1992). 
Table I. Reported [1] Reagents and Quantities in Np-bearing Uranophane Synthesis Experiment and Calculated Component Concentrations in Initial Solution

\begin{tabular}{|c|c|c|c|}
\hline Reagent & Reported Quantity & Component & Molality \\
\hline $\mathrm{UO}_{2}\left(\mathrm{CH}_{3} \mathrm{COO}\right)_{2} \cdot 2 \mathrm{H}_{2} \mathrm{O}$ & $5 \mathrm{~mL}$ at $0.2 \mathrm{M}$ & $\mathrm{Na}^{+}$ & 0.239 \\
\hline $\mathrm{Na}_{2} \mathrm{SiO}_{3} .9 \mathrm{H}_{2} \mathrm{O}$ & $0.227 \mathrm{~g}$ & $\mathrm{SiO}_{2}$ & 0.119 \\
\hline $\mathrm{Ca}\left(\mathrm{CH}_{3} \mathrm{COO}\right)_{2} \cdot \mathrm{H}_{2} \mathrm{O}$ & $0.282 \mathrm{~g}$ & $\mathrm{Ca}^{2+}$ & 0.239 \\
\hline $\mathrm{Np}(\mathrm{V})$ & $\approx 350 \mathrm{ppm}^{*}$ & $\mathrm{CH}_{3} \mathrm{COO}^{-}$ & 0.777 \\
\hline $\mathrm{HClO}_{4}$ & $\begin{array}{l}1 \mathrm{M} \text { to make } \\
\mathrm{pH} 5.4 \text { solution }\end{array}$ & $\begin{array}{l}\mathrm{UO}_{2}^{2+} \\
\mathrm{NpO}_{2}^{+}\end{array}$ & $\begin{array}{l}0.149 \\
1.27 \times 10^{-3}\end{array}$ \\
\hline $\begin{array}{l}\text { * prior to addition of acic } \\
\text { from a stock solution of } \\
\text { dissolved in } 3.626 \mathrm{~mL} \text { o }\end{array}$ & $\begin{array}{l}\mathrm{g} \mathrm{HClO}_{4} \text { solution, } \\
5 \mathrm{mg} \mathrm{Np}(\mathrm{V}) \\
\mathrm{ICClO}_{4}\end{array}$ & $\begin{array}{l}\mathrm{HClO}_{4} \\
\mathrm{pH}\end{array}$ & $\begin{array}{l}0.238 \\
5.4\end{array}$ \\
\hline
\end{tabular}

Table II. Principal Aqueous Species and Concentrations (Molal Except pH) in the Model Solution at $100^{\circ} \mathrm{C}$ at Equilibrium with $\mathrm{Np}$-bearing Uranophane

$\begin{array}{llll}\mathrm{CH}_{3} \mathrm{COOH} & 3.56 \times 10^{-1} & \mathrm{NpO}_{2}^{+} & 8.10 \times 10^{-4} \\ \mathrm{CH}_{3} \mathrm{COO}^{-} & 1.48 \times 10^{-1} & \mathrm{NpO}_{2} \mathrm{CH}_{3} \mathrm{COO} & 3.40 \times 10^{-4} \\ \mathrm{Ca}\left(\mathrm{CH}_{3} \mathrm{COO}\right)_{2} & 6.23 \times 10^{-2} & \mathrm{UO}_{2} \mathrm{CH}_{3} \mathrm{COO}_{3}^{-} & 2.30 \times 10^{-2} \\ \mathrm{CaCH}_{3} \mathrm{COO}^{+} & 4.78 \times 10^{-2} & \mathrm{UO}_{2} \mathrm{CH}_{3} \mathrm{COO}_{2} & 7.40 \times 10^{-3} \\ \mathrm{Ca}^{2+} & 6.88 \times 10^{-2} & \mathrm{UO}_{2} \mathrm{CH}_{3} \mathrm{COO}^{+} & 2.21 \times 10^{-4} \\ \mathrm{Cl}^{-} & 2.30 \times 10^{-1} & \mathrm{UO}_{2} \mathrm{OH}^{+} & 1.59 \times 10^{-5} \\ \mathrm{Na}^{+} & 2.14 \times 10^{-1} & \mathrm{UO}_{2}{ }^{2+} & 1.39 \times 10^{-5} \\ \mathrm{NaCH}_{3} \mathrm{COO} & 1.79 \times 10^{-2} & \mathrm{pH}^{-} & 4.37 \\ \mathrm{SiO}_{2} & 3.71 \times 10^{-4} & \text { Ionic strength } & 4.41 \times 10^{-1}\end{array}$


Table III. Predominant Equilibrium Species in Unsaturated Zone Waters from Yucca Mountain (Molal Concentrations Except pH) (Interpreted from Data in [30])

\section{Pore Water Perched Water \\ UZ14.144.8-145.2 UZ14B387.68m}

$\begin{array}{lll}\mathrm{AlO}_{2}^{-} & \text {no data } & 2.21 \times 10^{-4} \\ \mathrm{Br}^{-} & \text {no data } & 5.01 \times 10^{-6} \\ \mathrm{Ca}^{2+} & 1.51 \times 10^{-3} & 7.33 \times 10^{-4} \\ \mathrm{CaSO}_{4} & 8.22 \times 10^{-5} & 8.42 \times 10^{-6} \\ \mathrm{Cl}^{-} & 2.17 \times 10^{-3} & 2.34 \times 10^{-4} \\ \mathrm{HCO}_{3}^{-} & 1.93 \times 10^{-3} & 2.44 \times 10^{-3} \\ \mathrm{CO}_{2} \text { (aq) } & 3.47 \times 10^{-5} & 3.99 \times 10^{-5} \\ \mathrm{~K}^{+} & 3.56 \times 10^{-4} & 1.12 \times 10^{-4} \\ \mathrm{Mg}^{2+} & 4.36 \times 10^{-4} & 1.05 \times 10^{-4} \\ \mathrm{MgSO}_{4} & 4.84 \times 10^{-5} & 2.44 \times 10^{-6} \\ \mathrm{Na}^{+} & 2.08 \times 10^{-3} & 1.73 \times 10^{-3} \\ \mathrm{SO}_{4}{ }^{2-} & 9.21 \times 10^{-4} & 1.57 \times 10^{-4} \\ \mathrm{SiO}_{2}(\mathrm{aq}) & 1.34 \times 10^{-3} & 8.42 \times 10^{-4} \\ \mathrm{HSiO}_{3}^{-} & 1.84 \times 10^{-5} & 1.27 \times 10^{-5} \\ \mathrm{NO}_{3}^{-} & 3.53 \times 10^{-4} & 2.72 \times 10^{-4} \\ \mathrm{pH}^{-4} & 8.05 & 8.10\end{array}$

Table IV. Uranium, Neptunium, Uranyl, and Neptunyl in Model Yucca Mountain Groundwaters (Molal Concentrations)

\section{Pore Water Perched Water}

$\begin{array}{lll}\mathrm{U}(\text { total }) & 1.07 \times 10^{-7} & 3.15 \times 10^{-7} \\ \mathrm{UO}_{2}\left(\mathrm{CO}_{3}\right)_{3}{ }^{4-} & 5.94 \times 10^{-8} & 1.81 \times 10^{-7} \\ \mathrm{UO}_{2}\left(\mathrm{CO}_{3}\right)_{2}{ }^{2-} & 4.41 \times 10^{-8} & 1.28 \times 10^{-7} \\ \mathrm{UO}_{2}(\mathrm{OH})_{2} & 2.61 \times 10^{-9} & 5.00 \times 10^{-9} \\ \mathrm{UO}_{2}{ }^{2+} & 6.44 \times 10^{-15} & 8.73 \times 10^{-15} \\ \mathrm{~Np}(\text { total }) & 8.55 \times 10^{-10} & 1.60 \times 10^{-9} \\ \mathrm{NpO}_{2}{ }^{+} & 5.72 \times 10^{-10} & 9.47 \times 10^{-10} \\ \mathrm{NpO}_{2} \mathrm{CO}_{3}^{-} & 2.08 \times 10^{-10} & 5.05 \times 10^{-10} \\ \mathrm{NpO}_{2} \mathrm{OH} & 7.26 \times 10^{-11} & 1.39 \times 10^{-10}\end{array}$

